\title{
Quality and Sensory Properties of Reduced Fat Yoghurt Made with Addition of $\beta$-Glucans
}

\author{
Eleni C. Pappa1, Efthymia Kondyli1 ${ }^{*}$, William MacNaughtan², Athanasia Kakouri', \\ Konstantinos Nesseris ${ }^{3}$, Cleanthes Israilides ${ }^{4}$
}

\author{
${ }^{1}$ Dairy Research Department, Institute of Technology of Agricultural Products, Hellenic Agricultural Organization-DEMETER, \\ Katsikas, Greece \\ ${ }^{2}$ Division of Food Sciences, School of Biosciences, University of Nottingham, Sutton Bonington Campus, \\ Loughborough, UK \\ ${ }^{3}$ DODONI S.A., 1 Tagmatarchi Kostaki, Eleousa, Greece \\ ${ }^{4}$ Institute of Technology of Agricultural Products, Hellenic Agricultural Organisation-DEMETER, 1 S.Venizelou, Lycovrysi, \\ Greece \\ Email: *kondyliefi@gmail.com
}

How to cite this paper: Pappa, E.C., Kondyli, E., MacNaughtan, W., Kakouri, A., Nesseris, K. and Israilides, C. (2018) Quality and Sensory Properties of Reduced Fat Yoghurt Made with Addition of $\beta$-Glucans. Food and Nutrition Sciences, 9, 390-402. https://doi.org/10.4236/fns.2018.94031

Received: March 26, 2018

Accepted: April 27, 2018

Published: April 30, 2018

Copyright $\odot 2018$ by authors and Scientific Research Publishing Inc. This work is licensed under the Creative Commons Attribution International License (CC BY 4.0).

http://creativecommons.org/licenses/by/4.0/

(c) (i) Open Access

\begin{abstract}
$\beta$-Glucans, isolated from Pleurotus citrinopileatus mushroom, were used in the manufacture of yoghurt from reduced fat cow milk with added proteins. $\beta$-Glucans were added to the milk in the form of a paste containing $1.21 \%$ (on a dry weight basis) of $\beta$-glucans, such that the final concentrations in the yoghurt were $0.3 \%, 0.4 \%$ and $0.5 \%$. Control yoghurt was also manufactured from the same milk without the addition of $\beta$-glucans. The resultant yoghurts were examined for their physicochemical and microbial characteristics, gel formation and sensory properties and compared to the control at $1,7,14$ and 21 days of storage. Results showed that the microbial population, $\mathrm{pH}$, titratable acidity, ash and syneresis were not affected by the addition of different levels of glucans. The lowest fat, total solids and protein contents were recorded in the yoghurt containing $0.5 \%$ glucan. The yoghurt containing $0.3 \% \beta$-glucan had the same viscosity as the control and the yoghurt containing $0.5 \% \beta$-glucan had the lowest viscosity. Yoghurt with $\beta$-glucans received slightly higher scores for flavour, appearance and texture than the control. It was concluded that the incorporation of $0.3 \%$ or $0.4 \%$ $\beta$-glucans isolated from edible mushrooms, into the yoghurt does not affect the final product, which is similar or sensorially even better than the control.
\end{abstract}

\section{Keywords}

$\beta$-glucans, Functional, Yoghurt, Pleurotus citrinopileatus Mushroom 


\section{Introduction}

Yoghurt is a product of the lactic acid fermentation of milk by addition of homofermentative lactic acid bacteria Streptococcus thermophilus and Lactobacillus delbrueckii subsp. bulgaricus [1]. Over recent years an increase in the consumption of yoghurt and other acid fermented dairy products has been observed because of their perceived beneficial dietary and enhanced flavour properties. Moreover, it is known that dietary fat has been shown to be associated with an increased risk of obesity, atherosclerosis, coronary heart disease, elevated blood pressure and tissue injury diseases associated with lipid oxidation [2]. The association of fat with the above mentioned risks and the progressive awareness of consumers for their health and diet have created a high demand for low-fat foods, including yoghurt, with similar organoleptic properties to conventional full-fat products.

Functional foods, in particular the prebiotic category, play an important role in the modern dairy industry. Prebiotics are defined as non-digestible food ingredients that have a beneficial effect on the health of the host, selectively stimulating growth and/or the activity of a limited number of bacteria in the colon [3]. $\beta$-Glucan is recognised worldwide as a functional bioactive prebiotic ingredient and its use in the fortification of foods is of great interest [4]. It has been reported to have special properties such as cholesterol reduction [5], blood glucose regulation [6] and also potential antitumor and immunomodulating properties [7] [8] [9]. The Food and Drug Administration (FDA) has approved the claim regarding the cholesterol lowering effect of $\beta$-glucan at a level of $3 \mathrm{~g} /$ day [10].

Although there has been great interest in the fortification of yoghurt to further improve its nutritional value and benefits to health, there are very limited reports of the fortification of yoghurt with $\beta$-glucan. Sahan et al. [11] investigated the use of $\beta$-glucan hydrocolloidal composite as a fat substitute in the manufacture of non-fat yoghurts. Kilic and Akpinar [12] examined the effects of different levels of oat $\beta$-glucan on full fat yoghurts manufactured with probiotic adjunct culture. Vasiljevic et al. [13] studied the effects of addition of $\beta$-glucan from different cereal sources (oat and barley) on the growth and metabolic activity of probiotic organisms in yoghurt. Brennan and Tudorica [14] determined the possible beneficial effects of barley beta-glucan, as a fat substitute on the rheological, textural and sensory quality of low-fat yoghurt. Singh et al. [15] added oat $\beta$-glucan to low-fat yoghurt without noticeably affecting the texture or other key characteristics of it.

The use of mushrooms in nutrition comes from ancient years. Pleurotus citrinopileatus is an edible mushroom classified in the family Pleurotaceae, belonging to the Basidiomycetes species. It is found in China, Europe, Japan, Korea, North America, Siberia and Turkey. $\beta$-Glucan of Pleurotus citrinopileatus has many health improving effects, such as immunity stimulation and an anticancer effect [16]. It has also been shown to decrease cholesterol levels [17]. 
There are few reports which demonstrate the structural features of polysaccharides isolated from Pleurotus citrinopileatus, including ( $1 \rightarrow 3)-\beta$-D-glucan and $(1 \rightarrow 6)$ - $\beta$-D-glucosyl branched $(1 \rightarrow 3)-\beta$-D-glucan [18], and a branched $(1 \rightarrow 6)$ - $\beta$-D-glucan [19].

To the authors' knowledge, there is no report in the literature regarding the fortification of yoghurt with $\beta$-glucans isolated from mushrooms. Therefore, the objective of the present work was to add different concentrations of $\beta$-glucan, isolated from Pleurotus citrinopileatus mushroom to reduced fat yoghurt from cow milk and to examine whether the microbiological, physicochemical, textural and sensorial characteristics are affected. This research may benefit the dairy industry by generating new products with improved health benefits to consumers.

\section{Materials and Methods}

\subsection{Isolation and Measurement of $\beta$-Glucan from Pleurotus Citrinopileatus Mushroom}

The method of Wang and Zhang [20], with some modifications, was used. Briefly, the fruiting body of Pleurotus citrinopileatus mushroom was frozen $\left(-20^{\circ} \mathrm{C}\right)$, cut to pieces, freeze dried $\left(-75^{\circ} \mathrm{C}\right.$ for $\left.24 \mathrm{~h}\right)$, lyophilized and powdered. The powder of mushroom was defatted with ethanol by using a Soxhlet extractor for $8 \mathrm{~h}$. The resultant residue was immersed in $0.9 \% \mathrm{NaCl}$ solution at $70^{\circ} \mathrm{C}$ for $24 \mathrm{~h}$, centrifuged at $5700 \mathrm{rpm}$ for $10 \mathrm{~min}$ to remove the water-soluble polysaccharide and the residue was extracted with $1 \mathrm{M} \mathrm{NaOH}$ at $40^{\circ} \mathrm{C}$ for $8 \mathrm{~h}$. The supernatant was neutralized by $1 \mathrm{M} \mathrm{CH}_{3} \mathrm{COOH}$. The deposition ( $\beta$-glucan) was collected and washed with distilled water several times to achieve bleaching. $\beta$-Glucan in this stage is referred as $\beta$-glucan in the form of paste. The deposition after the several washing with distilled water was lyophilized to get a powder and $\beta$-glucan in this stage is referred as $\beta$-glucan in dry form.

Total glucans were hydrolyzed by using the enzymes exo,1,3- $\beta$-glucanase and $\beta$-glucanase; measurement of glucose molecules was followed. $\alpha$-Glucans were hydrolyzed by the enzymes amyloglucosidase and $\alpha$-amylase. $\beta$-Glucan was measured using the following equation: $\beta$-glucan $=($ total glucan + oligomers $)-$ (a-glucan + oligomers) [21].

\subsection{Structure of $\beta$-Glucan}

Structural and purity characteristics of $\beta$-glucan isolated from Pleurotus citrinopileatus mushroom, have been studied using solid state CPMAS (cross polarization magic angle spinning) NMR [22]. ${ }^{13} \mathrm{C}$ CPMAS NMR spectra were recorded on a Bruker AVANCE III 600 NMR spectrometer (Karlsruhe, Germany) with a narrow bore magnet and 4-mm triple resonance probe. The samples were packed into $4-\mathrm{mm}$ rotors and spun at $10 \mathrm{kHz}$. Chemical shifts (ppm) scales were referenced to the up field peak of adamantane $(29.5 \mathrm{ppm})$ run as an external standard under identical conditions. For all CPMAS experiments a contact time 
of $2 \mathrm{msec}$ was used. This contact time was close to the maximum signal intensity generation as determined by a variable contact time experiment. 2048 scans were recorded and an exponential line broadening of $15 \mathrm{~Hz}$ was applied. The presence of $\beta$-glucan was indicated by the carbon 1 signal having a peak chemical shift value close to $104 \mathrm{ppm}$.

\subsection{Preliminary Experiments}

Preliminary experiments aimed at the determination of the most suitable form of $\beta$-glucan that was best incorporated in the yoghurt mass. For this reason, $\beta$-glucan either in dry form (powder), or in the form of paste, was added in the milk used for yoghurt manufacture. Prior adding to the milk, the paste was centrifuged twice at $6000 \mathrm{rpm}$, at room temperature, for $15 \mathrm{~min}$ (Heraus CHRIST, Varifuge $\mathrm{K}, \mathrm{GmbH}$, Ostercode, Germany) to reduce its moisture content.

The paste or the powder was first dispersed in a small quantity of reduced fat milk with added proteins, at $75^{\circ} \mathrm{C}$ for $60 \mathrm{~min}$; then was added to the rest of the milk. Yoghurt was produced as described in the section that follows.

\subsection{Experimental Design}

The experiment was conducted at the Dairy Department of the Institute of Technology of Agricultural Products. Dodoni S.A. provided the reduced fat cow milk, with added proteins, that was used for the production of yoghurt. On the day of yoghurt making, the milk was divided into four equal parts. In each part, the required quantity of the paste of $\beta$-glucans was added such that the $\beta$-glucan final concentration in the yoghurt to be $0.0 \% \mathrm{w} / \mathrm{w}$ (control), $0.3 \% \mathrm{w} / \mathrm{w}(\mathrm{G} 0.3$ ), $0.4 \% \mathrm{w} / \mathrm{w}(\mathrm{G} 0.4)$ or $0.5 \% \mathrm{w} / \mathrm{w}$ (G0.5). This was repeated three times on a day after day basis. The reported results are, therefore, the averages of three trials.

\subsection{Yoghurt Manufacture}

Reduced fat cow milk, with added milk proteins was used for the manufacture of set type yoghurt. A mixture of two milk proteins was obtained from Arla Food Ingredients. The first (at proportion 70\%) is developed to give increased creaminess in yoghurt, while the second (at proportion 30\%) is used for high viscous fermented milk products. The composition of the mixture was: protein $74 \%$ $80 \%$, lactose $7 \%-12 \%$, maximum fat $5 \%$, maximum ash $7 \%$ and maximum moisture $6 \%$. The mixture quantity added in the milk was calculated such that its concentration in the yoghurt to be $7 \%$.

The milk for the yoghurt manufacture was boiled at $90^{\circ} \mathrm{C}$ for $15 \mathrm{~min}$ (for the maximal solubility of the paste) in an open kettle dipped in boiling water and cooled rapidly by tap water to $45^{\circ} \mathrm{C}$. Then the milk was inoculated with $2.5 \%$ (w/w) yoghurt starter culture of Streptococcus salivarious subsp. thermophilus and Lactobacillus delbrueckii subsp. bulgaricus (commercial cow yoghurt, DODONI S.A., with composition: fat 3.9\%, carbohydrates $4.9 \%$ and proteins $3.6 \%)$ and stirred well to ensure uniform distribution of the culture. Aliquots (200 
g) were poured into plastic containers and were incubated at $45^{\circ} \mathrm{C}$ until the $\mathrm{pH}$ decreased to 4.8. This required about 2.5 hours. Then yoghurt was cooled at $3^{\circ} \mathrm{C}$ to terminate acid development and was transferred to cold storage $\left(2^{\circ} \mathrm{C}-4^{\circ} \mathrm{C}\right)$.

\subsection{Physicochemical Analyses}

Milk protein, lactose, total solids and nonfat milk solids concentrations were measured in milk using near infrared spectrophotometry (Foss 605B Milko-Scan, Foss Electric, Hillerød, Denmark). pH was measured directly with a $\mathrm{pH}$ meter (Micro pH 2002; Crison, Barcelona, Spain).

The yoghurts were analysed for $\mathrm{pH}$ with a $\mathrm{pH}$ meter (Consort C931, Belgium), fat (Gerber method) [23], acidity (Dornic method; after mixing $10 \mathrm{~g}$ of yoghurt with an equal mass of distilled water) [24], total solids [25], ash [26] and protein content after total nitrogen determination by the Kjeldahl method [27].

\subsection{Syneresis Index}

Yogurt samples $(10 \mathrm{~g})$ were centrifuged at $1000 \times \mathrm{g}$ for $10 \mathrm{~min}$ at $8^{\circ} \mathrm{C}$ (Heraus CHRIST, Varifuge K, GmbH, Ostercode, Germany). The separated whey was decanted using a pipette and then weighed. The centrifuge tube was weighed to confirm the whey removed, too. Syneresis index was calculated as the weight of the whey separated per unit weight of yogurt.

\subsection{Measurement of Viscosity}

Viscosity was determined at $4^{\circ} \mathrm{C}$ using a viscometer (Brookfield Engineering Laboratories Inc, Massachusetts, USA; model RVT) with No 7 spindle at a speed of $2.5 \mathrm{rpm}$. The viscosity was derived from the maximum deflection of the needle on the scale after $1 \mathrm{~min}$ of shearing.

\subsection{Microbial Analyses}

Yoghurt samples were transferred aseptically to sterile polyethylene bags, $0.1 \%$ w/v buffered peptone water (BPW; Merck, Darmstadt, Germany) was added; the mixture was homogenized in a stomacher (Laboratory Blender, Seward, London, $\mathrm{UK}$ ) for $60 \mathrm{~s}$ at room temperature and appropriate dilutions in $0.1 \% \mathrm{BPW}$ were poured in or spread to duplicate agar plates.

Total viable counts (TVC) were determined on casein-peptone, soymeal-peptone (CASO) agar with $0.6 \%$ yeast extract; mesophilic and thermophilic lactic acid bacteria (LAB) on de Man, Rogosa, Sharpe (MRS) agar; thermophilic cocci on M-17 agar; total coliforms on violet red bile glucose agar, and yeasts on rose bengal chloramphenicol agar, according to the procedures reported by Bontinis et al. [28] and all microbiological counts were converted to $\log \mathrm{cfu} \cdot \mathrm{g}^{-1}$.

\subsection{Sensory Evaluation}

Sensory quality was assessed by five trained panel members who were permanent staff of the Dairy Department and experienced yoghurt tasters. The panel 
was asked to evaluate the appearance, body and texture and especially flavour of yoghurt and to notice any defects (wheying-off, lack of uniformity, fat separation etc). For this purpose, a five-point scale, with 1 being poor and 5 excellent, was used. The attribute of flavour was given dominating importance over the other two; therefore the score obtained for flavour was multiplied by two [29]. The total score, for the over-all acceptability, was obtained by adding the scores for the three attributes; therefore excellent yoghurt received a total score of 20. Water was provided for mouth washing between samples.

All the above analyses were performed at 1, 7, 14 and 21 days of cold storage $\left(2-4^{\circ} \mathrm{C}\right)$ of yoghurts.

\subsection{Statistical Analysis}

One-way analysis of variance was used for the comparison of the data of each parameter of yoghurt manufactured with different concentrations of $\beta$-glucans, at each age. Moreover, a comparison of the values of each parameter of yoghurt produced with one concentration of $\beta$-glucan at different ages was made. The least significant differences were obtained using the LSD test $(\mathrm{P}<0.05)$.

Statistical analysis was performed using statistical package STATGRAPHICS Plus for Windows version 5.2, Manugistics Inc., Rockville, MD, USA.

\section{Results and Discussion}

\subsection{Structure of $\beta$-Glucan}

Figure 1 shows a solid state ${ }^{13} \mathrm{C}$ CPMAS NMR spectrum of for $\beta$-glucan isolated from Pleurotus citrinopileatus. The presence of peaks in the region of $104 \mathrm{ppm}$ (C1) and 69 and $62 \mathrm{ppm}(\mathrm{C} 6)$ is consistent with the presence of $(1 \rightarrow 6),(1 \rightarrow 3)$ linked $\beta$-glucans as is the broad peak in the region of $86 \mathrm{ppm}$ (C3). However in this sample the presence of fairly intense peaks at 175, 56 and $23 \mathrm{ppm}$ is indicative of substantial contamination with chitin (Carbonyl, C2 and methyl groups respectively). The absence of aliphatic peaks in the region of 30ppm suggests minor contamination with proteins.

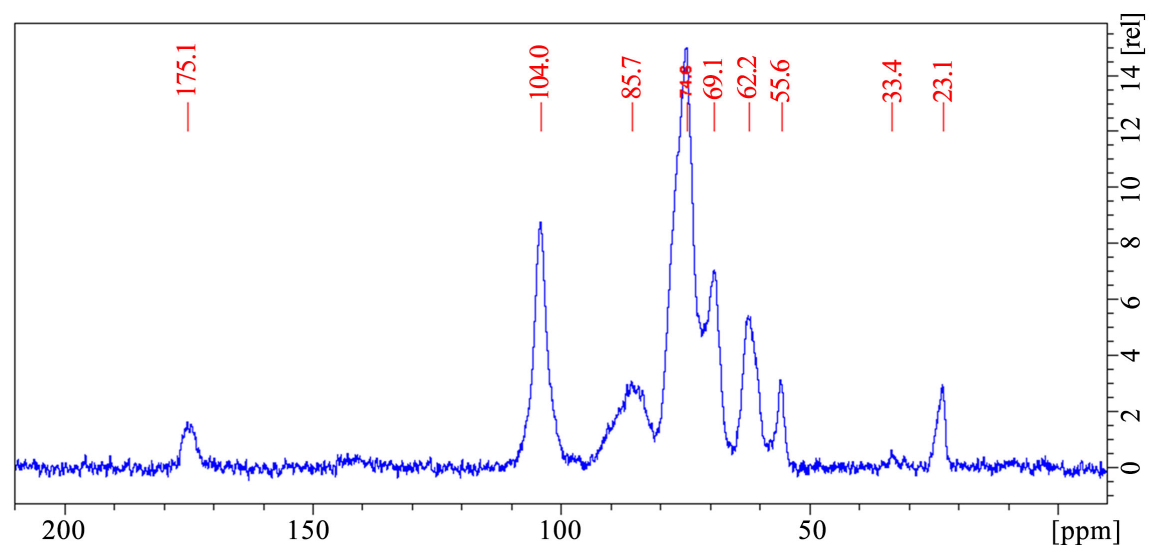

Figure 1. A solid state 13C CPMAS NMR trace for $\beta$-glucan isolated from Pleurotus citrinopileatus. See text for acquisition details. 


\subsection{Preliminary Experiments}

The paste had moisture $95.86 \%$ and ash content $0.0624 \%$. The $\beta$-glucan content of the paste and of the dry form (powder) was $70 \%$.

Results from the preliminary experiments have shown that $\beta$-glucan in lyophilized form (powder) was insoluble in milk (also undissolved in distilled water, results not shown); therefore the resulting yoghurt had a fair yellowish precipitate with an unpleasant flavour. On the contrary, $\beta$-glucan in the form of paste was dispersed well in the small portion of milk with no visible lumps and it was uniformly incorporated into the yoghurt mass. Therefore from the above preliminary results, it was decided to use $\beta$-glucan in the form of paste.

\subsection{Physicochemical Properties of Yoghurt}

The mean composition of cow milk used for the yoghurt preparation was: fat $2.48 \%$, protein $8.15 \%$, lactose $4.82 \%$, total solids $16.16 \%$ and $\mathrm{pH} 6.74$. Fat content of milk was lower whereas total solids and protein content were higher than those of cow milk, because reduced fat cow milk was enriched with proteins. Therefore, the composition of milk was typical of the standardised milk composition normally used in the dairy industry, for low fat yoghurt manufacture enriched with proteins (i.e. fat $2.50 \%$, protein $8.21 \%$, lactose $4.74 \%$ and total solids content $16.32 \%)$.

The physicochemical characteristics of yoghurt manufactured with or without addition of $\beta$-glucans, during storage are presented in Table 1 . The $\mathrm{pH}$ values for yoghurt samples at day 1 ranged from 4.57 to 4.67; decreased during storage and ranged from 4.26 to 4.29 at day 21 . These values were within the normal ranges for set-type yoghurts and were in accordance with others reports [11] [12]. The observed decrease in $\mathrm{pH}$ was obviously due to the continuous fermentation of lactose to lactic acid. Similar changes were found in titratable acidity of the yoghurts during storage (ranging from $0.97-0.99^{\circ} \mathrm{D}$ the first day to 1.09 $1.15^{\circ} \mathrm{D}$ the $21^{\text {st }}$ day). Addition of $\beta$-glucan did not significantly affect the values of $\mathrm{pH}$ and titratable acidity $(\mathrm{P}>0.05)$. Other researchers [30] [31] [32] also reported that $\mathrm{pH}$ values during storage were not significantly different between $\beta$-glucan containing and control yoghurts.

Ash content did not change significantly with storage time and with different levels of $\beta$-glucans in the yoghurts ( $\mathrm{P}>0.05$ ). It ranged from $0.88 \%-1.08 \%$ in the 1 st day of storage and $0.87 \%-1.09 \%$ at the end of 21 day-storage.

Fat, total solids and protein content did not differ significantly $(\mathrm{P}>0.05)$ during storage. At each storage day, the lowest fat, total solids and protein contents were determined in the yoghurt with addition of $0.5 \%$ glucan. Yoghurt with $0.3 \% \beta$-glucan did not differ in the fat, total solids and protein contents with control, while yoghurt with $0.4 \%$ glucan ranged in intermediate levels (Table 1 ). In this experiment, $\beta$-glucan was added in the form of paste, therefore increasing the level of $\beta$-glucan in the milk, the weight of paste was increased; resulting in an increase to the water content that was added in the milk. Also, from Table 1 
Table 1. Physicochemical characteristics of yoghurt made with different concentrations of $\beta$-glucan during storage.

\begin{tabular}{|c|c|c|c|c|c|c|c|c|c|}
\hline $\begin{array}{l}\text { Age } \\
\text { (Days) }\end{array}$ & Yoghurt & $\mathrm{pH}$ & acidity, ${ }^{\circ} \mathrm{D}$ & fat, $\%$ & total solids, $\%$ & protein, $\%$ & ash, $\%$ & syneresis & $\begin{array}{c}\text { viscosity, cP } \\
\left(\mathrm{mPa}^{*} \mathrm{~s}\right) \times 1000\end{array}$ \\
\hline \multirow{4}{*}{1} & $\mathrm{C}$ & $4.64 \pm 0.07 \mathrm{aA}$ & $0.99 \pm 0.04 \mathrm{aA}$ & $2.56 \pm 0.07 a A$ & $16.78 \pm 0.25 \mathrm{aA}$ & $8.46 \pm 0.14 \mathrm{aA}$ & $0.96 \pm 0.03 \mathrm{aA}$ & $0.19 \pm 0.04 \mathrm{aA}$ & $249.5 \pm 26.1 \mathrm{aAB}$ \\
\hline & G0.3 & $4.57 \pm 0.06 \mathrm{aA}$ & $0.97 \pm 0.04 \mathrm{aA}$ & $2.49 \pm 0.04 \mathrm{abA}$ & $16.52 \pm 0.36 \mathrm{abA}$ & $8.02 \pm 0.18 \mathrm{abA}$ & $1.08 \pm 0.14 \mathrm{aA}$ & $0.17 \pm 0.02 \mathrm{aA}$ & $215.5 \pm 2.5 \mathrm{abA}$ \\
\hline & G0.4 & $4.62 \pm 0.05 \mathrm{aA}$ & $0.99 \pm 0.01 \mathrm{aA}$ & $2.48 \pm 0.04 \mathrm{abA}$ & $16.05 \pm 0.34 \mathrm{abA}$ & $\mathrm{A} 7.45 \pm 0.21 \mathrm{bcA}$ & $0.89 \pm 0.01 \mathrm{aA}$ & $0.23 \pm 0.04 \mathrm{aA}$ & $205.5 \pm 29.5 \mathrm{abA}$ \\
\hline & G0.5 & $4.67 \pm 0.04 \mathrm{aA}$ & $0.98 \pm 0.01 \mathrm{Aa}$ & $2.30 \pm 0.0 \mathrm{bA}$ & $15.08 \pm 0.78 \mathrm{bA}$ & $6.96 \pm 0.53 \mathrm{cA}$ & $0.88 \pm 0.03 \mathrm{aA}$ & $0.18 \pm 0.03 \mathrm{aA}$ & $117.0 \pm 0.0 \mathrm{bA}$ \\
\hline \multirow{4}{*}{7} & $\mathrm{C}$ & $4.49 \pm 0.07 \mathrm{aA}$ & $1.16 \pm 0.08 \mathrm{aA}$ & $2.65 \pm 0.03 \mathrm{aA}$ & $17.07 \pm 0.24 \mathrm{aA}$ & $8.41 \pm 0.13 \mathrm{aA}$ & $0.99 \pm 0.02 \mathrm{aA}$ & $0.21 \pm 0.03 \mathrm{aA}$ & $247.6 \pm 14.4 \mathrm{aA}$ \\
\hline & G0.3 & $4.38 \pm 0.07 \mathrm{aB}$ & $1.11 \pm 0.06 \mathrm{aAB}$ & $2.64 \pm 0.11 \mathrm{abA}$ & $16.84 \pm 0.52 \mathrm{aA}$ & $7.96 \pm 0.21 \mathrm{aA}$ & $1.05 \pm 0.16 \mathrm{aA}$ & $0.17 \pm 0.04 \mathrm{aA}$ & $226.0 \pm 7.0 \mathrm{abA}$ \\
\hline & G0.4 & $4.37 \pm 0.04 \mathrm{aB}$ & $1.11 \pm 0.02 \mathrm{aB}$ & $2.48 \pm 0.04 \mathrm{bA}$ & $15.61 \pm 0.11 \mathrm{bA}$ & $7.31 \pm 0.14 \mathrm{bA}$ & $0.87 \pm 0.03 \mathrm{aA}$ & $0.25 \pm 0.03 \mathrm{aA}$ & $210.0 \pm 17.6 \mathrm{abA}$ \\
\hline & G0.5 & $4.43 \pm 0.02 \mathrm{aB}$ & $1.09 \pm 0.05 \mathrm{aA}$ & $2.30 \pm 0.00 \mathrm{Ca}$ & $15.00 \pm 0.60 \mathrm{bA}$ & $7.09 \pm 0.23 \mathrm{bA}$ & $0.88 \pm 0.06 \mathrm{aA}$ & $0.28 \pm 0.04 \mathrm{aAB}$ & $184.0 \pm 8.0 \mathrm{bB}$ \\
\hline \multirow{4}{*}{14} & $\mathrm{C}$ & $4.28 \pm 0.06 \mathrm{aB}$ & $1.13 \pm 0.06 \mathrm{aA}$ & $2.66 \pm 0.02 \mathrm{aA}$ & $17.11 \pm 0.24 \mathrm{aA}$ & $8.36 \pm 0.11 \mathrm{aA}$ & $0.98 \pm 0.04 \mathrm{aA}$ & $0.28 \pm 0.05 \mathrm{aA}$ & $312.6 \pm 20.2 \mathrm{aB}$ \\
\hline & G0.3 & $4.21 \pm 0.03 \mathrm{aB}$ & $1.16 \pm 0.03 \mathrm{aB}$ & $2.57 \pm 0.04 \mathrm{abA}$ & $16.40 \pm 0.29 \mathrm{abA}$ & $8.01 \pm 0.33 \mathrm{abA}$ & $1.04 \pm 0.12 \mathrm{aA}$ & $0.22 \pm 0.06 \mathrm{aA}$ & $225.7 \pm 18.6 \mathrm{bA}$ \\
\hline & G0.4 & $4.25 \pm 0.06 \mathrm{aB}$ & $1.08 \pm 0.05 \mathrm{aAB}$ & $2.51 \pm 0.07 \mathrm{bA}$ & $15.88 \pm 0.35 \mathrm{bA}$ & $7.58 \pm 0.20 \mathrm{bcA}$ & $0.89 \pm 0.03 \mathrm{aA}$ & $0.30 \pm 0.03 \mathrm{aA}$ & $168.7 \pm 22.2 \mathrm{bA}$ \\
\hline & G0.5 & $4.35 \pm 0.04 \mathrm{aBC}$ & $0.97 \pm 0.09 \mathrm{aA}$ & $2.30 \pm 0.00 \mathrm{cA}$ & $15.38 \pm 0.82 \mathrm{Ba}$ & $7.18 \pm 0.27 \mathrm{cA}$ & $0.86 \pm 0.05 \mathrm{aA}$ & $0.32 \pm 0.03 \mathrm{aB}$ & $184.0 \pm 29.0 \mathrm{bB}$ \\
\hline \multirow{4}{*}{21} & $\mathrm{C}$ & $4.29 \pm 0.07 \mathrm{aB}$ & $1.10 \pm 0.06 \mathrm{aA}$ & $2.69 \pm 0.07 \mathrm{aA}$ & $17.23 \pm 0.21 \mathrm{aA}$ & $8.26 \pm 0.11 \mathrm{aA}$ & $1.00 \pm 0.02 \mathrm{aA}$ & $0.27 \pm 0.03 \mathrm{aA}$ & $305.3 \pm 27.5 \mathrm{aAB}$ \\
\hline & G0.3 & $4.27 \pm 0.04 \mathrm{aB}$ & $1.12 \pm 0.06 \mathrm{aAB}$ & $2.57 \pm 0.04 \mathrm{abA}$ & $16.71 \pm 0.41 \mathrm{abA}$ & $8.39 \pm 0.41 \mathrm{aA}$ & $1.09 \pm 0.13 \mathrm{aA}$ & $0.21 \pm 0.05 \mathrm{aA}$ & $259.7 \pm 45.2 \mathrm{abA}$ \\
\hline & G0.4 & $4.26 \pm 0.02 \mathrm{aB}$ & $1.15 \pm 0.02 \mathrm{aB}$ & $2.56 \pm 0.06 \mathrm{abA}$ & $16.00 \pm 0.23 \mathrm{bcA}$ & $7.46 \pm 0.10 \mathrm{bA}$ & $0.90 \pm 0.05 \mathrm{aA}$ & $0.27 \pm 0.01 \mathrm{aA}$ & $188.3 \pm 15.4 \mathrm{bA}$ \\
\hline & G0.5 & $4.26 \pm 0.02 \mathrm{aC}$ & $1.09 \pm 0.07 \mathrm{aA}$ & $2.35 \pm 0.15 \mathrm{bA}$ & $15.35 \pm 0.60 \mathrm{dA}$ & $7.23 \pm 0.06 \mathrm{bA}$ & $0.87 \pm 0.10 \mathrm{aA}$ & $0.21 \pm 0.02 \mathrm{aAB}$ & $160.0 \pm 16.0 \mathrm{bAB}$ \\
\hline
\end{tabular}

Means 3 replicates \pm standard error, C: Control, G0.3: Yoghurt with addition of 0.3\% glucan, G0.4: Yoghurt with addition of 0.4\% glucan, G0.5: Yoghurt with addition of $0.5 \%$ glucan. a - d: For each parameter in the same column and at the same age, different letters indicate statistically significant differences between the type of yoghurts $(\mathrm{P}<0.05)$. A - C : For each parameter in the same column and for the same type of yoghurt, different capital letters indicate statistically significant differences between the storage age $(\mathrm{P}<0.05)$.

it can be seen that increasing the level of $\beta$-glucan in the yoghurts, generally the levels of fat, total solids and protein decreased during storage.

\subsection{Rheological and Structural Properties of Yoghurt}

Whey separation is defined as the appearance of whey (serum) on the gel surface of set-type yoghurts and is considered as an important defect of it. Syneresis is the shrinkage of the gel, which can lead to whey separation [32]. The increasing levels of $\beta$-glucan in the yoghurts did not affect significantly $(\mathrm{P}>0.05)$ syneresis (Table 1). Storage time did not affect $(\mathrm{P}>0.05)$ syneresis of control and yoghurts with $0.3 \%$ and $0.4 \% \beta$-glucan. However syneresis showed the lowest value at day 1 and the highest at day 14 , in the yoghurt with addition of $0.5 \% \beta$-glucan $(\mathrm{P}<0.05)$.

Increasing the level of $\beta$-glucan resulted in decrease $(\mathrm{P}<0.05)$ of the viscosity of the yoghurts (Table 1). Generally, yoghurt with $0.3 \% \beta$-glucan showed similar viscosity to the control and yoghurt with $0.5 \% \beta$-glucan had lower viscosity than them.

This observation can be attributed to the fact that $\beta$-glucan, as explained before, was added as a paste; therefore the higher the percentage of $\beta$-glucan added in the milk, the most water is found in the resulting yoghurt. However, other researchers [33] [34] have found that increasing the level of powder $\beta$-glucan in the milk, syneresis of yoghurts was decreasing and viscosity was increasing. 


\subsection{Microbial Properties of Yoghurt}

Table 2 shows the microbial content of control and yoghurt with added $\beta$-glucan, during the refrigerated storage. Total viable counts, total LAB, thermophilic cocci and thermophilic LAB did not change significantly during storage. Addition of $\beta$-glucan in yoghurts did not suppress the growth of starter culture and total LAB, thermophilic LAB and thermphilic cocci remained at 7.4 $8.73 \mathrm{log} \mathrm{cfu} / \mathrm{g}$ at the end of 21 days storage. Furthermore, Greek Codex Alimentarius [35] requires $10^{7} \log \mathrm{cfu} / \mathrm{g}$ starter culture until the end of the yoghurt shelf life and the results of this study fulfilled this requirement. Our results suggest that $\beta$-glucan was not digested and utilized by the yoghurt starter culture, as viable counts were not significantly different between the $\beta$-glucan-containing yoghurt and the control one, in accordance with the results of Kilic and Akpimar [12] and Kearney et al. [31]. All yoghurts, in this study, manufactured at the pilot plant of Dairy Department had coliforms and yeasts with counts below 1 and $2 \log \mathrm{cfu} / \mathrm{g}$, respectively; except yoghurt with $0.5 \% \beta$-glucan which at 21 -day of storage at $2-4^{\circ} \mathrm{C}$ showed $2.55 \mathrm{log} \mathrm{cfu} / \mathrm{g}$ yeasts (Table 2) and their presence could be attributed to post-production contamination, since the processing temperature $\left(90^{\circ} \mathrm{C}\right)$ used in the present study was high enough to inactivate them. It should also be mentioned that container filling was not aseptically performed.

\subsection{Sensory Properties of Yoghurt}

Sensory properties of the yoghurts are shown in Table 3. The expert panel indicated a preference (higher overall score) for yoghurts with $\beta$-glucan than the control one. Yoghurt with $0.3 \%$ glucan was preferred than control at 14 and 21 day and yoghurt containing $0.5 \% \beta$-glucan was preferred than control at 1 and 21 day. The panellists noticed glossier appearance, softer mouth-feel and less sour taste for yoghurt with $\beta$-glucans compared to the control. Appearance-color, texture, flavour and overall score did not differ with storage days $(\mathrm{P}>0.05)$, at all yoghurt samples. Appearance scores were not significantly affected by increasing the level of $\beta$-glucan in yoghurts. Generally, texture scores were the lowest in control yoghurt. As it can be seen from Table 3, flavour scores did not differ between $(\mathrm{P}>0.05)$ yoghurts with different levels of $\beta$-glucan.

\section{Conclusion}

The results of the present study showed that $\beta$-glucans isolated from Pleurotus citrinopileatus mushrooms, technically, could be incorporated in the yoghurt in the form of paste and not in dry form. Investigating the addition of different concentrations of $\beta$-glucans from mushroom ( $0.3 \%, 0.4 \%, 0.5 \%)$, the best results were obtained by addition of $0.3 \%$. This concentration, generally, did not significantly influence the microbial population, physicochemical characteristics, syneresis index and viscosity of the yoghurt. However, further studies are needed 
Table 2. Microbiological characteristics (log cfu/g) of yoghurt made with different concentrations of $\beta$-glucan during storage.

\begin{tabular}{|c|c|c|c|c|c|c|c|}
\hline $\begin{array}{c}\text { Age } \\
\text { (Days) }\end{array}$ & Yoghurt & Total Viable Counts & Total LAB & Thermophilic LAB & Thermophilic cocci & Yeasts & Coliforms \\
\hline \multirow{4}{*}{1} & $\mathrm{C}$ & $8.47 \pm 0.16 \mathrm{aA}$ & $7.76 \pm 0.16 \mathrm{aA}$ & $7.90 \pm 0.10 \mathrm{aA}$ & $8.57 \pm 0.05 \mathrm{aA}$ & $<2$ & $<1$ \\
\hline & G0.3 & $8.61 \pm 0.27 \mathrm{aA}$ & $8.02 \pm 0.18 \mathrm{aA}$ & $8.07 \pm 0.15 \mathrm{aA}$ & $8.47 \pm 0.13 \mathrm{aA}$ & $<2$ & $<1$ \\
\hline & G0.4 & $8.64 \pm 0.14 \mathrm{aA}$ & $7.74 \pm 0.14 \mathrm{aA}$ & $7.88 \pm 0.08 \mathrm{aA}$ & $8.71 \pm 0.03 \mathrm{aA}$ & $<2$ & $<1$ \\
\hline & G0.5 & $8.87 \pm 0.13 \mathrm{aA}$ & $7.60 \pm 0.12 \mathrm{aA}$ & $7.58 \pm 0.28 \mathrm{aA}$ & $8.56 \pm 0.07 \mathrm{aA}$ & $<2$ & $<1$ \\
\hline \multirow{4}{*}{7} & $\mathrm{C}$ & $8.41 \pm 0.16 \mathrm{aA}$ & $7.66 \pm 0.27 \mathrm{aA}$ & $7.75 \pm 0.22 \mathrm{aAB}$ & $8.41 \pm 0.14 \mathrm{aA}$ & $<2$ & $<1$ \\
\hline & G0.3 & $8.68 \pm 0.13 \mathrm{aA}$ & $8.25 \pm 0.01 \mathrm{aA}$ & $8.19 \pm 0.03 \mathrm{aA}$ & $8.63 \pm 0.18 \mathrm{aA}$ & $<2$ & $<1$ \\
\hline & G0.4 & $8.47 \pm 0.37 \mathrm{aA}$ & $7.84 \pm 0.26 \mathrm{aA}$ & $8.14 \pm 0.13 \mathrm{aA}$ & $8.81 \pm 0.05 \mathrm{aA}$ & $<2$ & $<1$ \\
\hline & G0.5 & $8.36 \pm 0.43 \mathrm{aA}$ & $7.83 \pm 0.32 \mathrm{aA}$ & $7.94 \pm 0.02 \mathrm{aA}$ & $8.66 \pm 0.05 \mathrm{aA}$ & $<2$ & $<1$ \\
\hline \multirow{4}{*}{14} & $\mathrm{C}$ & $8.51 \pm 0.22 \mathrm{aA}$ & $7.75 \pm 0.16 \mathrm{aA}$ & $7.87 \pm 0.12 \mathrm{aA}$ & $8.55 \pm 0.04 \mathrm{aA}$ & $<2$ & $<1$ \\
\hline & G0.3 & $8.80 \pm 0.17 \mathrm{aA}$ & $8.20 \pm 0.13 \mathrm{aA}$ & $8.10 \pm 0.13 \mathrm{aA}$ & $8.69 \pm 0.18 \mathrm{aA}$ & $<2$ & $<1$ \\
\hline & G0.4 & $8.86 \pm 0.03 \mathrm{aA}$ & $7.87 \pm 0.16 \mathrm{aA}$ & $7.80 \pm 0.18 \mathrm{aA}$ & $8.79 \pm 0.13 \mathrm{aA}$ & $<2$ & $<1$ \\
\hline & G0.5 & $8.36 \pm 0.40 \mathrm{aA}$ & $7.78 \pm 0.06 \mathrm{aA}$ & $6.70 \pm 0.70 \mathrm{bA}$ & $8.71 \pm 0.23 \mathrm{aA}$ & $<2$ & $<1$ \\
\hline \multirow{4}{*}{21} & $\mathrm{C}$ & $8.72 \pm 0.06 \mathrm{aA}$ & $7.70 \pm 0.41 \mathrm{aA}$ & $7.26 \pm 0.31 \mathrm{aB}$ & $8.41 \pm 0.09 \mathrm{aA}$ & $<2$ & $<1$ \\
\hline & G0.3 & $8.73 \pm 0.17 \mathrm{aA}$ & $8.42 \pm 0.35 \mathrm{aA}$ & $7.48 \pm 0.59 \mathrm{aA}$ & $8.41 \pm 0.15 \mathrm{abA}$ & $<2$ & $<1$ \\
\hline & G0.4 & $8.82 \pm 0.09 \mathrm{aA}$ & $7.61 \pm 0.23 \mathrm{aA}$ & $7.84 \pm 0.19 \mathrm{aA}$ & $8.72 \pm 0.03 \mathrm{bA}$ & $<2$ & $<1$ \\
\hline & G0.5 & $8.62 \pm 0.09 \mathrm{aA}$ & $7.40 \pm 0.37 \mathrm{aA}$ & $7.46 \pm 0.31 \mathrm{aA}$ & $8.73 \pm 0.04 \mathrm{abA}$ & $2.55 \pm 0.34$ & $<1$ \\
\hline
\end{tabular}

Means 3 replicates \pm standard error, C: Control, G0.3: Yoghurt with addition of 0.3\% glucan, G0.4: Yoghurt with addition of 0.4\% glucan, G0.5: Yoghurt with addition of $0.5 \%$ glucan. a - d: For each parameter in the same column and at the same age, different letters indicate statistically significant differences between the type of yoghurts $(\mathrm{P}<0.05)$. A - B: For each parameter in the same column and for the same type of yoghurt, different capital letters indicate statistically significant differences between the storage age $(\mathrm{P}<0.05)$.

Table 3. Sensory evaluation of yoghurt made with different concentrations of $\beta$-glucan during storage.

\begin{tabular}{|c|c|c|c|c|c|}
\hline $\begin{array}{l}\text { Age } \\
\text { (Days) }\end{array}$ & Yoghurt & Appearance-Colour (5) & Texture (5) & Flavour (10) & Overall score (20) \\
\hline \multirow{4}{*}{1} & $\mathrm{C}$ & $4.64 \pm 0.18 \mathrm{aA}$ & $4.34 \pm 0.09 \mathrm{aA}$ & $8.36 \pm 0.26 \mathrm{aA}$ & $17.34 \pm 0.37 \mathrm{aA}$ \\
\hline & G0.3 & $4.72 \pm 0.08 \mathrm{aAB}$ & $4.68 \pm 0.15 \mathrm{abA}$ & $9.06 \pm 0.28 \mathrm{abA}$ & $18.46 \pm 0.51 \mathrm{abA}$ \\
\hline & G0.4 & $4.70 \pm 0.10 \mathrm{aA}$ & $4.64 \pm 0.11 \mathrm{abA}$ & $8.96 \pm 0.34 \mathrm{abA}$ & $18.30 \pm 0.42 \mathrm{abA}$ \\
\hline & G0.5 & $4.70 \pm 0.20 \mathrm{aA}$ & $4.90 \pm 0.10 \mathrm{bA}$ & $9.40 \pm 0.2 \mathrm{bA}$ & $19.00 \pm 0.3 \mathrm{bA}$ \\
\hline \multirow{4}{*}{7} & $\mathrm{C}$ & $4.77 \pm 0.07 \mathrm{aA}$ & $4.42 \pm 0.07 \mathrm{aA}$ & $8.71 \pm 0.21 \mathrm{aA}$ & $17.90 \pm 0.25 \mathrm{aA}$ \\
\hline & G0.3 & $4.63 \pm 0.12 \mathrm{aA}$ & $4.75 \pm 0.03 \mathrm{aA}$ & $9.10 \pm 0.45 \mathrm{aA}$ & $18.48 \pm 0.59 \mathrm{aA}$ \\
\hline & G0.4 & $4.44 \pm 0.39 \mathrm{aA}$ & $4.33 \pm 0.32 \mathrm{aA}$ & $8.28 \pm 0.86 \mathrm{aA}$ & $17.06 \pm 1.56 \mathrm{aA}$ \\
\hline & G0.5 & $4.90 \pm 0.10 \mathrm{aA}$ & $4.70 \pm 0.10 \mathrm{aA}$ & $9.20 \pm 0.2 \mathrm{aA}$ & $18.80 \pm 0.4 \mathrm{aA}$ \\
\hline \multirow{4}{*}{14} & $\mathrm{C}$ & $4.66 \pm 0.12 \mathrm{aA}$ & $4.24 \pm 0.07 \mathrm{aA}$ & $8.08 \pm 0.15 \mathrm{aA}$ & $16.98 \pm 0.16 \mathrm{aA}$ \\
\hline & G0.3 & $4.93 \pm 0.07 \mathrm{aB}$ & $4.87 \pm 0.04 \mathrm{bA}$ & $9.40 \pm 0.2 \mathrm{bA}$ & $19.21 \pm 0.26 \mathrm{cA}$ \\
\hline & G0.4 & $4.60 \pm 0.10 \mathrm{aA}$ & $4.70 \pm 0.06 \mathrm{bA}$ & $8.52 \pm 0.49 \mathrm{abA}$ & $17.82 \pm 0.44 \mathrm{abA}$ \\
\hline & G0.5 & $4.80 \pm 0.10 \mathrm{aA}$ & $4.75 \pm 0.05 \mathrm{bA}$ & $9.0 \pm 0.2 \mathrm{abA}$ & $18.55 \pm 0.35 \mathrm{bcA}$ \\
\hline \multirow{4}{*}{21} & $\mathrm{C}$ & $4.66 \pm 0.11 \mathrm{aA}$ & $4.32 \pm 0.09 \mathrm{aA}$ & $8.44 \pm 0.31 \mathrm{aA}$ & $17.42 \pm 0.45 \mathrm{aA}$ \\
\hline & G0.3 & $4.93 \pm 0.07 \mathrm{aB}$ & $4.83 \pm 0.03 \mathrm{bA}$ & $9.60 \pm 0.12 \mathrm{bA}$ & $19.37 \pm 0.21 \mathrm{bA}$ \\
\hline & G0.4 & $4.80 \pm 0.12 \mathrm{aA}$ & $4.70 \pm 0.12 \mathrm{bA}$ & $9.20 \pm 0.12 \mathrm{abA}$ & $18.70 \pm 0.31 \mathrm{bA}$ \\
\hline & G0.5 & $4.80 \pm 0.10 \mathrm{aA}$ & $4.65 \pm 0.15 \mathrm{abA}$ & $9.20 \pm 0.2 \mathrm{abA}$ & $18.65 \pm 0.45 \mathrm{abA}$ \\
\hline
\end{tabular}

Means 3 replicates \pm standard error, C: Control, G0.3: Yoghurt with addition of 0.3\% glucan, G0.4: Yoghurt with addition of 0.4\% glucan, G0.5: Yoghurt with addition of $0.5 \%$ glucan. Values in parentheses are maximum attainable scores. a - $\mathrm{d}$ : For each parameter in the same column and at the same age, different letters indicate statistically significant differences between the type of yoghurts $(\mathrm{P}<0.05)$. A - B: For each parameter in the same column and for the same type of yoghurt, different capital letters indicate statistically significant differences between the storage age $(\mathrm{P}<0.05)$.

in order to determine if the addition of $\beta$-glucan from Pleurotus citrinopileatus at different concentrations affects proteolysis, lipolysis or the aroma development of the yoghurts during storage. 


\section{Acknowledgements}

The authors thank DODONI SA for financial support of this study.

\section{References}

[1] Tamime, A.Y. and Robinson, R.K. (1999) Yoghurt Science and Technology. 2nd Edition, Woodhead Publishing, Cambridge.

[2] Warensjo, E., Nolan, D. and Tapsell, L. (2010) Dairy Food Consumption and Obesity-Related Chronic Disease. In: Taylor, S.L., Ed., Advances in Food and Nutrition Research, Volume 59, Elsevier, Amsterdam, 1-42.

[3] Gibson, G.R. and Roberfroid, M.B. (1995) Dietary Modulation of the Human Colonic Microbiota: Introducing the Concept of Prebiotics. Journal of Nutrition, 125, 1401-1414.

[4] Cui, W. and Wood, P.J. (2000) Relationship between Structural Features, Molecular Weight and Rheological Properties of Cereal $\beta$-Glucan. In: Nishinari, K., Ed., $H y$ drocolloids, Elsevier, Amsterdam, 159-168. https://doi.org/10.1016/B978-044450178-3/50019-6

[5] Commission Regulation (EU) No1160/2011, Official Journal of the European Union, 15-11-2011.

[6] Lazaridou, A. and Biliaderis, C.G. (2007) Molecular Aspects of Cereal $\beta$-Glucan Functionality: Physical Properties, Technological Applications and Physiological Effects. Journal of Cereal Science, 46, 101-118. https://doi.org/10.1016/j.jcs.2007.05.003

[7] Tsang, K.W., Lam, C.L., Yan, C., Mak, J.C., Ooi, G.C., Ho, J.C., Lam, B., Man, R., Sham, J.S. and Lam W.K. (2003) Coriolus Versicolor Polysaccharide Peptide Slows Progression of Advanced Non-Small Cell Lung Cancer. Respiratory Medicine, 97, 618-624. https://doi.org/10.1053/rmed.2003.1490

[8] Tada, R., Harada, T., Nagi-Miura, N., Adachi, Y., Nakadjima, M., Yadomae, T. and

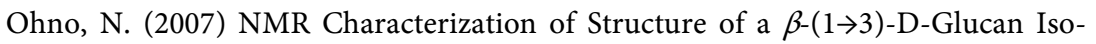
lated from Cultured Fruit Bodies of Sparassis crispa. Carbohydrate Research, 342, 2611-2618. https://doi.org/10.1016/j.carres.2007.08.016

[9] Eleftheriadis, E., Mavraganis, V.G. and Israilidis, C. (2014) The Potential Use of Mushrooms $\beta$-Glucans in the Food Industry. International Journal of Biotechnology for Wellness Industries, 3, 15-18. https://doi.org/10.6000/1927-3037.2014.03.01.3

[10] Food and Drug Administration (FDA) (2005) Food Labelling: Health Claims; Oat and Coronary Heart Disease; Final Rule Federal Register Doc. 97-1598, Filed 1-22-1997.

[11] Sahan, N., Yasar, K. and Hayaloglu, A.A. (2008) Physical, Chemical and Flavor Quality of Non-Fat Yoghurt as Affected by a $\beta$-Glucan Hydrocolloidal Composite during Storage. Food Hydrocolloids, 22, 1291-1297.

https://doi.org/10.1016/j.foodhyd.2007.06.010

[12] Kilic, G.B. and Akpinar, D. (2013) The Effects of Different Levels of $\beta$-Glucan on Yoghurt Manufactured with Lactobacillus plantarum Strains as Adjunct Culture. Journal of Food Agriculture and Environment, 11, 281-287.

[13] Vasiljevic, T., Kealy, T. and Mishra, V.K. (2007) Effects of $\beta$-Glucan Addition to a Probiotic Containing Yoghurt. Journal of Food Science, 72, C405-C411. https://doi.org/10.1111/j.1750-3841.2007.00454.x

[14] Brennnan, C.S. and Tudorica, C.M. (2008) Carbohydrate-Based Fat Replacers in the Modification of the Rheological, Textural and Sensory Quality of Yoghurt: Com- 
parative Study of the Utilisation of Barley Beta-Glucan, Guar Gum and Inulin. International Journal of Food Science and Technology, 43, 824-833. https://doi.org/10.1111/j.1365-2621.2007.01522.x

[15] Singh, M., Kim, S. and Liu, S.X. (2012) Effect of Purified Oat $\beta$-Glucan on Fermentation of Set-Style Yoghurt Mix. Journal of Food Science, 77, E195-E201. https://doi.org/10.1111/j.1750-3841.2012.02828.x

[16] Minato, K.K. (2008) Immunomodulation Activity of a Polysaccharide Fraction of a Culinary-Medicinal Mushroom, Pleurotus citrinopileatus Singer (Agaricomycetideae), in Vitro. International Journal of Medicinal Mushroom, 10, 235-244. https://doi.org/10.1615/IntJMedMushr.v10.i3.40

[17] Rop, O., Mlcek, J. and Jurikova, T. (2009) Beta-Glucan in Higher Fungi and Their Health Effects. Nutrition Reviews, 67, 624-631. https://doi.org/10.1111/j.1753-4887.2009.00230.x

[18] Zhang, J., Wang, G., Li, H., Zhuang, C., Mizuno, T., Ito, H., Suzuki, C., Okamoto, H. and Li, J. (1994) Antitumor Polysaccharides from a Chinese Mushroom, "Yuhuangmo" the Fruiting Body of Pleurotus Citrinopileatus. Bioscience Biotechnology and Biochemistry, 58, 1195-1201. https://doi.org/10.1271/bbb.58.1195

[19] Liu, J., Sun, Y., Yu, H., Zhang, C., Yue, L., Yang, X., Wang, L. and Liu, J. (2012) Purification and Identification of One Glucan from Golden Oyster Mushroom (Pleurotus citrinopileatus (Fr.) Singer). Carbohydrate Polymers, 87, 348-352. https://doi.org/10.1016/j.carbpol.2011.07.059

[20] Wang, J. and Zhang, L. (2009) Structure and Chain Conformation of Five Water-Soluble Derivatives of a $\beta$-d-Glucan Isolated from Ganoderma lucidum. Carbohydrate Research, 344, 105-112. https://doi.org/10.1016/j.carres.2008.09.024

[21] Megazyme (2016) Mushroom and Yeast Beta Glucan Assay Procedure, Megazyme International. http://www.megazyme.com

[22] Fricova, O. and Kovalakova, M. (2013) Solid-State 13 C CP MAS NMR Spectroscopy as a Tool for Detection of $(1 \rightarrow 3,1 \rightarrow 6)-\beta$-D-Glucan in Products Prepared from Pleurotus ostreatus. Analytical Chemistry, 20, 13.

[23] B.S.I. (1955) Gerber Method for the Determination of Fat in Milk and Milk Products. British Standard 696. British Standards Institution, London.

[24] Ling, R. (1963) A Text Book of Dairy Chemistry. 3rd Edition, Vol. 2, Chapman and Hall Ltd., London.

[25] I.D.F. (1958) Determination of Dry Matter in Cheese and Processed Cheese. IDF Standard 4. International Dairy Federation, Brussels.

[26] I.D.F. (1964) Determination of the Ash Content of Processed Cheese Products. International Dairy Federation, Brussels.

[27] I.D.F. (1986) Milk. Determination of Nitrogen Content (Kjeldahlmethod) and Calculation of Crude Protein Content. IDF Standard 20A. International Dairy Federation, Brussels.

[28] Bontinis, T.G., Mallatou, H., Alichanidis, E., Kakouri, A. and Samelis, J. (2008) Physicochemical, Microbiological and Sensory Changes during Ripening and Storage of Xinotyri, a Traditional Greek Cheese from Raw Goat's Milk. International Journal of Dairy Technology, 61, 229-236. https://doi.org/10.1111/j.1471-0307.2008.00404.x

[29] Pearce, L.E. and Heap, H.A. (1974) Town Milk. Journal of New Zealand Milk Board, 22, 18.

[30] Gee, V.I., Vasanthan, T. and Temelli, F. (2007) Viscosity of Model Systems Enriched with $\beta$-Glucan as Influenced by Starter Cultures. International Dairy Journal, 
17, 1083-1088. https://doi.org/10.1016/j.idairyj.2007.01.004

[31] Kearney, N., Sack, H.M., Tobin, J., Chaurin, V., Fenelon, M.A., Fitzgerald, G.F., Ross, R.P. and Stanton, C. (2011) Lactobacillus paracasei NFBC 338 Producing Recombinant Beta-Glucan Positively Influences the Functional Properties of Yoghurt. International Dairy Journal, 21, 561-567.

https://doi.org/10.1016/j.idairyj.2011.03.002

[32] Lucey, J.A. (2004) Cultured Dairy Products: An Overview of Their Gelation and Texture Properties. International Journal of Dairy Technology, 57, 77-84. https://doi.org/10.1111/j.1471-0307.2004.00142.x

[33] Tudorica, C.M., Eirian, T., Jones, R., Kuri, V. and Brennan, C.S. (2004) The Effects of Refined Barley $\beta$-Glucan on the Physico-Structural Properties of Low-Fat Dairy Products: Curd Yield, Microstructure, Texture and Rheology. Journal of the Science of Food and Agriculture, 84, 1159-1169. https://doi.org/10.1002/jsfa.1789

[34] Rinaldi, L., Rioux, L.E., Britten, L. and Turgein, S.L. (2015) In Vitro Bioaccessility of Peptides and Aminoacids from Yoghurt Made with Starch, Pectin or $\beta$-Glucan. International Dairy Journal, 46, 39-45. https://doi.org/10.1016/j.idairyj.2014.09.005

[35] National Printing Office (2016) Greek Codex Alimentarius for Foodstuff and Beverages. Official Journal of the Hellenic Republic, B, Article 82. 